UNIO - EU Law Journal. Vol. 5, No. 2, July 2019, pp 15-33.

®2019 Centre of Studies in European Union Law

School of Law - University of Minho

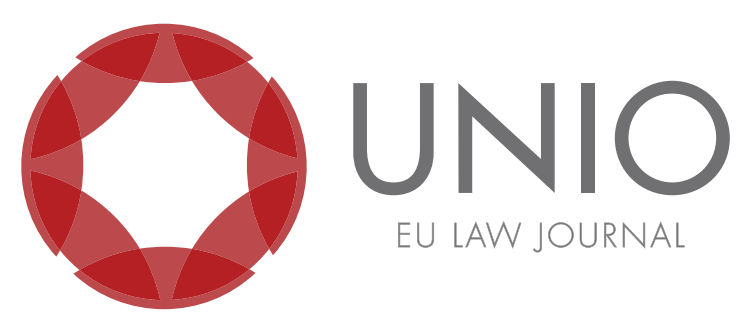

\title{
Electronic commerce and the fashion industry: new challenges for competition law coming from the Digital Single Market
}

\section{Caterina Fratea*}

ABSTRACT: Digital technology has changed our markets to an extent last seen during the industrial revolution and electronic commerce has been growing steadily over the last decade. This paper intends to assess how the development of online sales has affected market strategies and the application of competition law, with a particular focus on the selective distribution agreements within the fashion industry. Secondly, the case law of the Court of Justice of the European Union is analysed in order to show how certain new contractual clauses, that have become frequent in the digital commercial landscape, require competition rules to be read under a new lens. The final part is dedicated to the recent Geo-blocking Regulation which represents one the most significant measures within the Digital Single Market, highlighting both its coordination with antitrust provisions and its application when competition law does not apply.

KEYWORDS: Digital Single Market - e-Commerce - selective distribution agreements - fashion industry-geo-blocking.

\footnotetext{
*Assistant Professor of European Union Law, University of Verona, Department of Law. The present paper falls within the research activities team "The Fashion Hub" established within the Department of Law of the University of Verona, appointed as Department of Excellence 2018-2022 by Italian Ministry of University and Research.
} 


\section{Introduction}

On 6 May 2015, the European Commission launched a sector inquiry into the electronic commerce of consumer goods and digital content in the EU, pursuant to Article 17 of Council Regulation No. $1 / 2003 .{ }^{1}$ The e-commerce sector inquiry forms part of the Digital Single Market Strategy adopted on the same day, ${ }^{2}$ which is built on three pillars: (i) a better access for consumers and businesses to online goods and services across Europe, which requires the rapid removal of key differences between the online and offline worlds to break down barriers to cross-border online activity; (ii) the creation of the right conditions for digital networks and services to flourish, which requires fair competition rules and a level playing field; and, finally, (iii) the maximization of the growth potential of the European digital economy. ${ }^{3}$

The conclusions of the Final Report on the E-commerce Sector Inquiry (based on information collected by retailers, marketplaces, price comparison tool providers, payment system providers, manufacturers, digital content providers, companies offering virtual private networks and IP routing services, and large groups and hosting operators) ${ }^{4}$ clearly show that the growth of e-commerce over the last decade has been undeniable. ${ }^{5}$ This steady development led to an increased online price transparency and price competition but also had a significant impact on companies' business models and consumers' behaviour.

From the companies' point of view, new market trends and distribution strategies have been brought about. A large proportion of manufacturers decided to sell their products directly to consumers through their own online retail shops, thereby competing increasingly with their own distributors. Moreover, an increased use of selective distribution systems, where the products can only be sold by preselected authorised sellers, has been registered allowing manufacturers to better control their distribution networks, in particular in terms of the quality of distribution and price. Finally, an increased use of contractual restrictions to better control product

\footnotetext{
${ }^{1}$ Regulation (EC) No. 1/2003 of 16.12 .2002 on the implementation of the rules on competition laid down in Articles 81 and 82 of the Treaty, in OJ L 1 of 4.1.2003, 1-25. Article 17(1) establishes that " [w] here the trend of trade between Member States, the rigidity of prices or other circumstances suggest that competition may be restricted or distorted within the common market, the Commission may conduct its inquiry into a particular sector of the economy or into a particular type of agreements across various sectors. In the course of that inquiry, the Commission may request the undertakings or associations of undertakings concerned to supply the information necessary for giving effect to Articles 81 and 82 of the Treaty and may carry out any inspections necessary for that purpose. The Commission may in particular request the undertakings or associations of undertakings concerned to communicate to it all agreements, decisions and concerted practices. The Commission may publish a report on the results of its inquiry into particular sectors of the economy or particular types of agreements across various sectors and invite comments from interested parties".

${ }^{2}$ See European Commission, Communication to the European Parliament, the Council, the European Economic and Social Committee and the Committee of the Regions, "A Digital Single Market Strategy for Europe", Brussels, 6.5.2015, COM(2015) 192 final.

${ }^{3}$ Para. 1 of the Communication.

${ }^{4}$ See also, Assonime contribution to the Commission Consultation on the Preliminary Report on the E-Commerce Sector Inquiry, 24.12.2016, intervento 20-2016, last accessed 27.4.2019, available at http://www. assonime.it/attivita-editoriale/interventi/Pagine/268834.aspx.

5 "Final Report on the E-commerce Sector Inquiry", Brussels, 10 May 2017, COM(2017) 229 final, para. 3: "Today the EU is one of the largest e-commerce markets in the world. The percentage of people aged between 16 and 74 that have ordered goods or services over the internet has grown year-on-year from $30 \%$ in 2007 to $55 \%$ in 2016". See Lars Kjølbye, Alessio Aresu and Sophia Stephanou, "The Commission's E-commerce Sector Inquiry - Analysis of Legal Issues and Suggested Practical Approach", Journal of European Competition Law \& Practice 6 (2015): 465-476.
} 
distribution has taken place. Depending on the business model and strategy, such restrictions may take various forms, such as pricing restrictions, marketplace (platform) bans, restrictions on the use of price comparison tools and exclusion of pure online players from distribution networks.

Some of these practices may be justified, for example in order to improve the quality of product distribution. Others, instead, may unduly prevent consumers from benefitting from greater product choice and lower prices in e-commerce and therefore, warrant Commission action to ensure compliance with EU competition rules. Besides, the new strategies brought higher tensions between traditional 'brick-and-mortar' distributors and online distributors, who can afford more competitive prices in the absence of higher fixed costs related to a physical point of sale. ${ }^{6}$

The present paper is intended to analyse how the new digital scenario has affected EU competition law and how the EU institutions have reacted in order to face this growing phenomenon.

\section{EU competition law and the positive effects of vertical agreements on the market}

When it comes to fashion industry, the aspects of EU competition law that are mostly relevant can be identified with the provisions on anticompetitive agreements set out in Article 101 TFEU, ${ }^{7}$ in particular with the rules on vertical agreements or concerted practices between two or more undertakings. According to Article 1(1)(a) and (for the purposes of) Commission Regulation No. 330/2010 (so-called Vertical Block Exemption Regulation, hereinafter VBER), "vertical agreement means an agreement or concerted practice entered into between two or more undertakings each of which operates, for the purposes of the agreement or the concerted practice, at a different level of the production or distribution chain, and relating to the conditions under which the parties may purchase, sell or resell certain goods or services". ${ }^{8}$ Besides the agreements between manufacturers, wholesalers and retailers, also those concluded between manufacturers must be considered if one produces the materials that are necessary to assemble the goods that are necessary to the other.

\footnotetext{
${ }^{6}$ On these aspects see Michal Gal, "Competition and innovation in the digital environment", in Concorrenza e comportamenti escludenti nei mercati dell'innovazione, a cura di Giuseppe Colangelo and Valeria Falce (Bologna: Il Mulino, 2017), 11-26, at 13.

${ }^{7}$ According to Article 101(1) TFEU, "[t] he following shall be probibited as incompatible with the internal market: all agreements between undertakings, decisions by associations of undertakings and concerted practices which may affect trade between Member States and which have as their object or effect the prevention, restriction or distortion of competition within the internal market, and in particular those which: (a) directly or indirectly fix purchase or selling prices or any other trading conditions; (b) limit or control production, markets, technical development, or investment; (c) share markets or sources of supply; (d) apply dissimilar conditions to equivalent transactions with other trading parties, thereby placing them at a competitive disadvantage; (e) make the conclusion of contracts subject to acceptance by the other parties of supplementary obligations which, by their nature or according to commercial usage, have no connection with the subject of such contracts". On Article 101 TFEU see, ex multis, Allison Jones and Brenda Sufrin, EU Competition Law, $6^{\text {th }}$ ed. (Oxford: Oxford University Press, 2016), 113; Vivien Rose and David Bailey (edited by), Bellamy \& Child European Union Law of Competition, $7^{\text {th }}$ ed. (Oxford: Oxford University Press, 2013), 81; Richard Wish and David Bailey, Competition Law, $9^{\text {th }}$ ed. (Oxford: Oxford University Press, 2018), 82.

${ }^{8}$ Commission Regulation (EU) No. 330/2010 of 20.4.2010 on the application of Article 101(3) of the Treaty on the Functioning of the European Union to categories of vertical agreements and concerted practices, in OJ L 102 of 23.4.2010, 1-7. For a wider analysis of this Regulation, see Rosa Magrí, Le intese verticali. Il regolamento di esenzione UE 330/10 (Catania: Lulu Press Inc., 2013).
} 
In the absence of a specific distinction between horizontal and vertical agreements enshrined in Article 101 TFEU, the Court of Justice of the European Union (hereinafter, CJEU), from the beginning of the European integration, has admitted that this provision prohibits any kind of anticompetitive agreements provided that they have an inter-State dimension, because both can restrict competition and create unjustified disadvantages for consumers. ${ }^{9}$

However, vertical agreements are considered less harmful for the maintenance of a competitive structure than the horizontal ones because, alongside some possible anticompetitive restraints, they are recognized to produce also some positive effects. It is true that negative effects are also likely to arise from a vertical agreement, like the anticompetitive foreclosure of the market for other suppliers or other buyers by raising barriers to entry or expansion; the softening of competition and/or facilitation of collusion amongst suppliers, often referred to as reduction of interbrand competition; the softening of competition between the buyer and its competitors and/or facilitation of collusion amongst these competitors, also referred to as reduction of intra-brand competition if it concerns distributors' competition on the basis of the brand or product of the same supplier; the creation of obstacles to market integration, including, above all, limitations on the possibilities for consumers to purchase goods or services in any Member State they may choose. ${ }^{10}$

Nonetheless, they can also produce some possible positive effects as, in particular, promoting non-price competition and improved quality of services (as in cases of selective distribution and franchising that require the distributor to have a certain standard of quality of the service connected to the image of the trade mark), opening up or entering new markets and promoting investments. ${ }^{11}$ Several reasons may lead to vertical economic and commercial integration: the reduction of transaction costs, the need of an uninterrupted supply of goods, the reduction of taxes, the weakening of a competitor's market power and the consequent acquisition of a stronger position in the market. Moreover, these agreements can represent an alternative to mergers when they are particularly difficult to implement or can turn out to be ineffective. Generally speaking, vertical agreements are aimed at making the buyer develop some activities that can be useful but expensive for the supplier (principal-agent relationship). ${ }^{12}$ Every undertaking needs their products to be distributed and the quality and efficiency of the distribution system are pivotal factors in the competitive game to gain the favour of clients. There are only a few manufacturers that directly sell to the final consumers, with the choice to rely upon specialized distributors being the usual one. In certain fields, strong economies can be created thanks to the cooperation of different operators of the commercial chain

\footnotetext{
${ }^{9}$ See judgment of the Court of Justice, Établissements Consten S.à.R.L. and Grundig-Verkaufs-GmbH v Commission of the European Economic Community, 13.7.1966, joined cases 56 and 58/64, EU:C:1966:41 (on Article 86 TEEC). Cp. Enzo Cannizzaro and Lorenzo Federico Pace, Capitolo VT. Le politiche di concorrenza, (Torino: Giappichelli, 2010), 293-349, at 300; Richard Wish and David Bailey, Competition Law, cited above, 121 (for the difference between vertical agreements and unilateral conduct see $109 \mathrm{ff}$.).

${ }^{10}$ Commission notice - Guidelines on Vertical Restraints, SEC(2010) 411, para. 100.

${ }^{11}$ Guidelines on Vertical Restraints, cited above, para. 106. See Frank Wijckmans and Filip Tuytschaever, Vertical Agreements in EU Competition Law (Oxford: Oxford University Press, 2011), para. 9.10; Richard Wish and David Bailey, Competition Law, cited above, 629.

${ }^{12}$ Philip Marsden and Peter Whelan, "Selective distribution in the age of online retail", European Competition Law Review 31 (2010): 27. When referred to vertical agreements, the terms «supplien» and «buyer» just mean two operators at a different level of the commercial chain, not being synonyms of «retailer» and «final purchaser» respectively.
} 
and this cooperation has been facilitated and strengthened by the so called "just-intime manufacturing". ${ }^{13}$

The positive effects generally connected to a vertical agreement must be linked to the so-called "rule of reason", which means that these agreements must be assessed by taking into account not only their object but also their possible effects in light of the economic context in which they are implemented. ${ }^{14}$ The theoretical starting point is that a supplier that, for instance, concludes an exclusive distribution agreement cannot be driven by an anticompetitive search of profits at the expenses of the buyer since the possible price increase deriving from the agreement (besides being forfeited by the distributor and not by the supplier) would result in a sales' contraction. An exclusive distribution agreement, that might cause an economic prejudice to the supplier due to the consequent price increase, is therefore justified by the possibility that the distributor can offer, together with the goods that are the object of the contract, additional services that result in an increase in the quality of goods and, consequently, in demand and profits. This scenario, protecting both the supplier and the distributor and bringing higher quality goods to the consumers, is considered far from being harmful to competition.

However, in order to assess whether a given vertical agreement brings these positive effects also in practice, it would be too simple to look only at the increase in the volumes of products sold since other crucial variables must be taken into account, such as the purchasers' behaviour. It is therefore, necessary to look first at the object of the agreement and, then, at its effects as Article 101 TFEU requires. ${ }^{15}$ This analysis is supported by the VBER listing the conditions under which vertical restraints are exempted from the prohibition on anticompetitive agreements defined by Article 101(1) TFEU, as well as the new Guidelines on Vertical Restraints, both adopted by the European Commission on 20 April 2010. These rules replaced Regulation

\footnotetext{
13 The "just-in-time manufacturing" (JIT) originally referred to the production of goods to meet customer demand exactly, in time, quality and quantity, whether the customer is the final purchaser of the product or another process further along the production line. It has now come to mean producing with minimum waste: see T.C.E. Cheng and S. Podolsky, Just-in-Time Manufacturing. An Introduction, $2^{\text {nd }}$ ed. (London: Springer, 1996), 9.

${ }^{14}$ Pietro Manzini, "Capitolo I. Le intese", in Il diritto antitrust dell'Unione europea, Bernardo Cortese, Fabio Ferraro and Pietro Manzini (Torino: Giappichelli, 2014), 1-43, at 22.

${ }^{15}$ On the distinction between restriction by object and by effect see, ex plurimis, Cristophe Lemaire, “Object vs. Effect After the Modernisation of EU Law: What Has (or Should Have) Changed?", in New Frontiers of Antitrust 2012 (Brussels: Bruylant, 2013), 163-182; Denis Waelbroeck and Donald Slater, The Scope of Object vs Effect Under Article 101 TFEU, in Ten years of effects-based approach in EU competition law. State of play and perspectives, eds. J. Bourgeois and Denis Waelbroeck (Brussels: Bruylant, 2013), 131-157; J. Killick and J. Jourdan, Cartes Bancaires: A Revolution or a Remainder of Old Principles We Should Never Have Forgotten?, 2014, last accessed 27.4.2019, available at https://www. competitionpolicyinternational.com/cartes-bancaires-a-revolution-or-a-reminder-of-old-principleswe-should-never-have-forgotten; Ginevra Bruzzone and Sara Capozzi, "Restrictions by Object in the Case Law of the Court of Justice: in search of a Systematic Approach", in L'applicazione delle regole di concorrenza in Italia e nell'Unione europea. Atti del V Convegno biennale Antitrust, Trento, 16-18 aprile 2015, a cura di Gian Antonio Benacchio, Michele Carpagnano (Napoli: Editoriale Scientifica, 2015), 217-236; Pietro Fattori, "The Impact of Groupement des Cartes Bancaires on Competition Law Enforcement", Italian Antitrust Review, No. 2 (2015): 22-28; Javier Ruiz Calzado and Andreas Scordamaglia-Tousis, "Groupement des Cartes Bancaires v Commission: Shedding Light on What is not a 'by object' Restriction of Competition", Journal of European Competition Law \& Practice 6 (2015): 495-498; Robert Schütze, European Union Law (Cambridge: Cambridge University Press, 2015), 701; Gian Luca Zampa and Alessandro Di Giò, "The Conundrum of Restrictions "by Object": Rationale, Scope, Impact and a Proposal", Italian Antitrust Review, No. 3 (2015): 13-44.
} 
No. $2790 / 1999^{16}$ and the previous Guidelines ${ }^{17}$ as of June 2010 and will remain in force until May 2022. While the 2010 Regulation does not contain other significant changes compared to 1999 Regulation, the new Guidelines contain a great number of adjustments and changes to the rules for how vertical restraints need to be assessed, from the Commission's perspective, in light of Article 101 TFEU. More precisely, when the Regulation does not apply because not all the conditions provided there are met, it is still possible to assess whether the vertical agreement can enjoy an individual exemption. The Guidelines represent the tool that has to be referred to when carrying out this evaluation.

\section{Vertical agreements within electronic commerce: where the EU institutions stand}

As anticipated in the previous paragraph, the potential positive effects that vertical agreements have on the market led the Commission to admit to the possibility of exempting them, under certain conditions, ${ }^{18}$ from the prohibition enshrined in Article 101(1) TFEU notwithstanding the potential anticompetitive effects based on the reduced competition among distributors that they imply.

The general idea underpinning the VBER and the Guidelines on Vertical Restraints is that the exemption does not cover vertical agreements that contain limitations on passive sales ${ }^{19}$ for the distributor, whereas limitations on active sales can be allowed, provided the other conditions are met. The secondary law provisions on vertical agreements are intended to strike a balance between these two interests: in fact, on the one hand, allowing limitations of active sales ensures the supplier that their distributors are not going to compete in the same territories or towards the same clients. In this way, distributors are also inclined to invest in advertisement and promotional activities without running the risk that their direct competitors take advantage of their efforts (so-called free-riding).$^{20}$ On the other hand, prohibiting limitations on passive sales, EU competition law makes it possible to maintain a certain level of intra-brand

\footnotetext{
${ }^{16}$ In OJ L 336 of 29.12.1999, 21-25.

${ }^{17}$ In OJ C 291 of $13.10 .2000,1-44$.

${ }^{18}$ There are different sets of conditions to be met: a market share threshold [the market share held by both the supplier and the buyer (distributor) shall not exceed 30\% of their respective relevant markets - Article 3 VBER]; the absence of any restriction of the buyer's ability to determine its sale price (without prejudice to the possibility of the supplier to impose a maximum sale price or recommend a sale price - Article 4(a) VBER); the absence of any restriction of the territory into which, or of the customers to whom, a buyer party to the agreement may sell the contract goods or services, except the restriction of active sales (i.e. the sales deriving from the promotional and client-research activity actively implemented by the distributor) into the exclusive territory or to an exclusive customer group reserved to the supplier or allocated by the supplier to another buyer, where such a restriction does not limit sales by the customers of the buyer, [Article 4(b)(i) VBER and para. 51 of the Guidelines on Vertical Restraints].

19 “'Passive' sales mean responding to unsolicited requests from individual customers including delivery of goods or services to such customers. General advertising or promotion that reaches customers in other distributors' (exclusive) territories or customer groups but which is a reasonable way to reach customers outside those territories or customer groups, for instance to reach customers in one's own territory, are considered passive selling. General advertising or promotion is considered a reasonable way to reach such customers if it would be attractive for the buyer to undertake these investments also if they would not reach customers in other distributors' (exclusive) territories or customer groups" (para. 51 of the Guidelines on Vertical Restraints).

${ }^{20}$ For an analysis of free-riding concerns in the e-commerce sector, see Ioannis Apostolakis, "E-commerce and free rider considerations under Article 101 TFEU", European Competition Law Review 37 (2016): 114-121.
} 
competition and to compete on price and other market conditions, since (distributors are well aware that) consumers tend to go elsewhere, should the retailers increase prices or tighten other contractual conditions excessively.

In the internet scenario, therefore, it becomes rather critical to give the correct legal definition to some restrictions that are strictly related to the e-commerce sector. If these restrictions affect active sales, they will be permitted; not the same if they affect passive sales.

The European Commission displayed a very favourable attitude towards online sales. The internet is considered "a powerful tool to reach a greater number and variety of customers than by more traditional sales methods, which explains why certain restrictions on the use of the internet are dealt with as (re)sales restrictions. In principle, every distributor must be allowed to use the internet to sell products". ${ }^{21}$ The Commission thus regards the following as examples of hardcore restrictions of passive selling given the capability of these restrictions to limit the distributor's access to a greater number and variety of customers: (a) any agreement preventing the distributor from undertaking any kind of online sales provided that the distributor's decision to use a website to sell products is considered a form of passive selling, ${ }^{22}$ (b) an agreement that the (exclusive) distributor shall prevent customers located in another (exclusive) territory from viewing its website or shall automatically re-rout its customers to the manufacturer's or other (exclusive) distributors' websites; ${ }^{23}$ (c) an agreement that the (exclusive) distributor shall terminate consumers' transactions over the internet once their credit card data reveal an address that is not within the distributor's (exclusive) territory; (d) an agreement that the distributor shall limit its proportion of overall sales made over the internet; however, the supplier may require that the buyer sells at least a certain absolute amount (in value or volume) of the products offline to ensure an efficient operation of its brick and mortar shop; ${ }^{24}$ (e) an agreement that the distributor shall pay a higher price for products intended to be resold by the distributor online than for products intended to be resold offline: however, the supplier may agree with the buyer a fixed fee (that is, not a variable fee where the sum increases with the realised offline turnover as this would amount indirectly to dual pricing) to support the latter's offline or online sales effort. ${ }^{25}$

In this context, one might wonder whether the growing development of online sales, whose degree was perhaps not completely foreseen by the Commission in 2010, broke the above described balance between limitation of intra-brand competition and protection of price-based competition. ${ }^{26}$ The increase of online sales volume is,

\footnotetext{
${ }^{21}$ Para. 52 of the Guidelines on Vertical Restraints.

${ }^{22}$ The same is true if a customer opts to be kept (automatically) informed by the distributor and it leads to a sale. Offering different language options on the website does not, of itself, change the passive character of such selling (ibidem).

${ }^{23}$ This does not exclude an agreement that the distributor's website shall also offer a number of links to websites of other distributors and/or the supplier (ibidem).

${ }^{24}$ This absolute amount of required offline sales can be the same for all buyers, or determined individually for each buyer on the basis of objective criteria, such as the buyer's size in the network or its geographic location (ibidem).

${ }^{25}$ Ibidem. See Vito Auricchio, Matteo Padellaro and Paolo Tomassi, Gli accordi di distribuzione commerciale nel diritto della concorrenza (Padova: CEDAM, 2013), 474.

${ }^{26}$ Cp. Josefine Hederström and Luc Peeperkorn, "Vertical Restraints in On-line Sales: Comments on Some Recent Developments", Journal of European Competition Law \& Practice 7, No. 1 (2016): 10-23; Aldo Frignani and Alessandra Sonnati, "La distribuzione via internet nell'Unione europea prima e dopo il Regolamento No. 330/2010: i giudici hanno compreso l'economia di internet?", Diritto del commercio internazionale 30 (2016): 627-650.
} 
in fact, due to the fact that for a wide range of goods and services, it is no longer necessary for the consumers to go to a physical point of sale, to be made aware of their main characteristics. The consumer, thanks to the knowledge transferred by the internet, is totally capable of finding autonomously the distributor that guarantees the most favourable conditions. This makes almost totally ineffective certain exclusive distribution agreements or exclusive customer allocation agreements.

Notwithstanding this, the limitation of passive sales will not, presumably, be allowed by the Commission: not only does the online channel guarantee a higher volume of sales, but also, if the online and offline systems are mutually replaceable, this means that neither the limitation of active sales (done with exclusive distribution agreements or exclusive customer allocation agreements), motivated with the aim of avoiding free-riding by competitors, finds no real justification.

\section{Selective distribution agreements and electronic contracts: the view of the CJEU from Pierre Fabre...}

Selective distribution agreements represent a very widespread tool within the distribution chains. ${ }^{27}$ As a general rule, there are three possible situations in which these agreements are not falling within the prohibition of Article 101(1) TFEU: either they comply with the well-known Metro case law (in this case they would not even be considered anticompetitive $)^{28}$ or they can be exempted under the VBER if all the conditions set therein are met, or, eventually, they can be granted an individual exemption.

With the recent and fast-growing increase of the electronic commerce, a number of new clauses which could be included in selective distribution agreements have been developed. This has largely changed the commercial scenario and induced to read the typical tools of competition law under a new lens. These clauses fall, essentially, into three general categories: ${ }^{29}(1)$ clauses restricting the use of the internet in the context of distribution contracts, whose aim is to eliminate or to limit passive sales; (2) clauses restricting the use of online platforms in the context of selective distribution contracts; (3) parity clauses (or MFNs clauses) which require the supplier from selling through the internet to link the terms of contract arranged with its online platform to the terms of the contracts agreed with the competitors of the latter. In the perspective of the protection of competition, these clauses have drawn new problems and recently have been the subject of significant intervention from EU institutions.

The present analysis focuses on the first two categories of clauses, which are most commonly related to the fashion industry. The first case where the CJEU faced the

\footnotetext{
${ }^{27}$ According to Article 1(1)(e) VBER, "selective distribution system' means a distribution system where the supplier undertakes to sell the contract goods or services, either directly or indirectly, only to distributors selected on the basis of specified criteria and where these distributors undertake not to sell such goods or services to unauthorised distributors within the territory reserved by the supplier to operate that system". See Joana Whyte, "Direito da Concorrência à la Mode", in Direito da Moda, vol. I, coordenação Ligia Carvalho Abreu, Francisco Pereira Coutinho (Lisboa: Universidade Nova de Lisboa, 2019), 206-208.

${ }^{28}$ Judgment of the Court of Justice, 25.10.1977, case 26/76, EU:C:1977:167, where the Court stated that these agreements comply with the present Article 101(1) TFEU "provided that resellers are chosen on the basis of objective criteria of a qualitative nature relating to the technical qualifications of the reseller and his staff and the suitability of his trading premises and that such conditions are laid down uniformly for all potential resellers and are not applied in a discriminatory fashion" (para. 20).

${ }^{29}$ For a general overview of these clauses see the "Preliminary Report on the E-commerce Sector Inquiry”, Brussels, 15.9.2016, SWD(2016) 312 final.
} 
issue regarding the first category of clauses, i.e. contractual clauses that, within selective distribution systems, prohibit or limit online sales is the Pierre Fabre case, ${ }^{30}$ dealing with a general and absolute ban on internet sales imposed by the supplier of cosmetics and personal care products on authorised distributors. In this decision, the Court examines two different profiles: first whether such a clause represents a restriction to competition; secondly, if so, whether the clause can nonetheless be authorized according to the VBER.

As to the first profile, the aim of maintaining a prestigious image, argued by Pierre Fabre, is not considered a legitimate aim for restricting competition and cannot, therefore, justify that a contractual clause pursuing such an aim fall outside Article 101(1) TFEU. A contractual clause requiring sales of cosmetics and personal care products to be made in a physical space where a qualified pharmacist must be present, resulting in a ban on the use of the internet for those sales, amounts to a restriction by object where, following an individual and specific examination of the content and objective of that contractual clause and the legal and economic context of which it forms a part, it is apparent that, having regard to the properties of the products at issue, that clause is not objectively justified. ${ }^{31}$

As to the second profile, Article 4(c) of the VBER comes into consideration, according to which the restriction of active or passive sales to end users by members of a selective distribution system operating at the retail level of trade is considered a hardcore restriction. However, the provision authorises the supplier to prevent a member of the system from operating out of an unauthorised place of establishment. ${ }^{32}$ The question, then, was if the internet fell within the definition of 'place of establishment', so that it could be possible for the supplier to ban its use.

According to the Court, Article 4(c) VBER only concerns outlets where direct sales take place. Also, the Court excluded a broad interpretation through which that expression can be taken to encompass the place from which internet sales services are provided. Therefore, not being possible to invoke that exception, the Court concluded that a contractual clause prohibiting de facto the internet as a method of marketing, at the very least has as its object, the restriction of passive sales to end users wishing to purchase online and located outside the physical trading area of the relevant member of the selective distribution system ${ }^{33}$ (unless such a contract may benefit, on an individual basis, from the exception provided for in Article 101(3) TFEU where the conditions of that provision are met).

In the reasoning of the Court, some passages remain obscure. In particular, the Court defined the absolute online sales ban as a restriction by object unless that clause is not objectively justified, but it does not make it clear which elements could

\footnotetext{
${ }^{30}$ Judgment of the Court of Justice 11.10.2011, case C-439/09, EU:C:2011:649. See, ex multis, Laurence Idot, "Distribution sélective et Internet”, Europe, No. 12 (Décembre, 2011): 471; Jorren Knibbe, "Selective Distribution and the ECJ's Judgment in Pierre Fabre", European Competition Law Review 33 (2012): 450-451; Catherine Robin, "Est-il interdit d'interdire la vente sur Internet des produits cosmétiques?", Revue Lamy de la Concurrence: droit, économie, régulation 67, No. 30 (2012): 23-24; Valerio Cosimo Romano, "ECJ Ruling on the Prohibition of On-line Sales in Selective Distribution Networks", Journal of European Competition Law \& Practice 3 (2012): 345-347; Alexandre L. Dias Pereira, "Vertical restraints on internet sales in EU competition law", European Competition Law Review 38 (2017): 478-482.

${ }^{31}$ Paras. $46-47$ of the Pierre Fabre decision.

${ }^{32}$ The wording of the provision remains unchanged in both the 1999 and the 2010 VBERs.

${ }^{33}$ Paras. 54 and 56-57 of the Pierre Fabre decision.
} 
objectively justify such a restriction. From the opinion of Advocate General Mazák, the reference seems to be to needs of consumers' protection, when he argues "that, in certain exceptional circumstances, private voluntary measures limiting the sale of goods or services via the internet could be objectively justified, by reason of the nature of those goods or services or the customers to whom they are sold". ${ }^{34}$

\section{V.... to Coty. Which online passive sales restrictions are allowed?}

It is beyond doubt that in the Pierre Fabre ruling, the CJEU stated that the aim of maintaining a prestigious image is not a legitimate aim for restricting competition. Were this statement to be regarded as a general principle, the conclusion would be that not only an absolute ban, but any kind of contractual clause imposing a restriction on internet sales with the aim to preserve the same interest should be deemed as anticompetitive.

The CJEU's subsequent case law proves that this is not the case. In the Coty judgment, the Court deals with the issue of online platform restrictions in selective distribution contracts with an innovative approach. ${ }^{35}$ In this case, the contractual clause at stake did not prevent distributors from resorting to the online channel, but from making use of a non-authorised third party in the context of internet sales.

After recalling that any selective distribution system, limiting competition among distributors, leads in practice to anticompetitive restrictions, the Court's assessment focuses on the possibility of justifying such clause by means of the Metro criteria. ${ }^{36}$ In doing this, the Court overcomes the firm statement made in Pierre Fabre and establishes that selective distribution "may be considered necessary in respect of luxury goods, since the quality of such goods is not just the result of their material characteristics, but also of the allure and prestigious image which bestow on them an aura of luxury, that that aura is essential in that it enables consumers to distinguish them from similar goods and, therefore, that an impairment to that aura of luxury is likely to affect the actual quality of those goods". ${ }^{37}$

This conclusion stems from recalling the case law on trademarks and, in particular, the Copad case ${ }^{38}$. According to this case law, the establishment of a selective distribution system which seeks to ensure that the goods are displayed in sales outlets in a manner that enhances their value contributes to the reputation of the goods at issue and therefore to sustaining the aura of luxury surrounding them. ${ }^{39}$ It follows that, provided that the other criteria enshrined in the Metro case law are also met, a

\footnotetext{
${ }^{34}$ Opinion of 11.3.2011, para. 35.

${ }^{35}$ Judgment of the Court of Justice, 6.12.2017, case C-230/16, EU:C:2017:941. See, ex multis, Stefan Wartinger and Lukas Solek, "Restrictions of Third-Party Platforms within Selective Distribution Systems", World Competition 39, No. 2 (2016): 291-305; Andrea Cicala, Kurt Haegmann and Rachel Cuff, "From Metro to Coty: a story to be continued? The CJEU's judgment in Coty Germany GmbH v Parfümerie Akzente GmbH", Italian Antitrust Law Review, No. 2 (2017): 99-111; Ariel Ezrachi, "The Ripple Effects of Online Marketplace Bans”, World Competition 40, No. 1 (2017): 47-63; Maria Casoria and Roberto Pardolesi, "La Corte di Giustizia e il (re)wind della distribuzione selettiva nella rete. Il caso Coty Germany", Mercato concorrenza regole 20, No. 2 (2018): 75-88; Giuseppe Colangelo and Valerio Torti, "Selective distribution and online marketplace restrictions under EU competition rules after Coty Prestige", European Competition Journal 14 (2018): 81-109; Denis Waelbroeck and Zachariah Davies, "Coty, Clarifying Competition Law in the Wake of Pierre Fabre", Journal of European Competition Law \& Practice 9 (2018): 431-442; Joana Whyte, "Direito da Concorrência à la Mode", cited above, 213-219.

${ }^{36}$ See footnote 29.

${ }^{37}$ Para. 25 of the Coty decision.

${ }^{38}$ Judgment of the Court of Justice, 23.4.2009, case C-59/08, EU:C:2009:260.

${ }^{39}$ Paras. 27 of the Coty decision and 29 of the Copad decision.
} 
selective distribution system designed, primarily, to preserve the luxury image of those goods is compatible with Article 101(1) TFEU. More specifically, the Court recognized as lawful a contractual clause which prohibits authorised distributors in a selective distribution system for luxury goods designed to preserve the luxury image of those goods from using, in a discernible manner, third-party platforms for the internet sale of the contract goods, on condition that that clause has the objective of preserving the luxury image of those goods, that it is laid down uniformly and not applied in a discriminatory fashion, and that it is proportionate in light of the objective pursued.

With regards to the appropriateness of the prohibition at issue in light of the objective pursued, the Court observes, first, that the obligation imposed on authorised distributors to sell the contract goods online solely through their own online shops and the prohibition on those distributors of using a different business name, as well as the use of third-party platforms in a discernible manner, provide the supplier with a guarantee, from the outset, in the context of electronic commerce, that those goods will be exclusively associated with the authorised distributors.

Second, the prohibition at issue in the main proceedings enables the supplier of luxury goods to check that the goods will be sold online in an environment that corresponds to the qualitative conditions that it has agreed with its authorised distributors. The internet sale of luxury goods via platforms which do not belong to the selective distribution system for those goods, in the context of which the supplier is unable to check the conditions in which those goods are sold, involves a risk of deterioration of the online presentation of those goods which is liable to harm their luxury image and thus their very character.

Third, given that those platforms constitute a sales channel for goods of all kinds, the fact that luxury goods are not sold via such platforms and that their sale online is carried out solely in the online shops of authorised distributors contributes to that luxury image among consumers and thus, to the preservation of one of the main characteristics of the goods sought by consumers. ${ }^{40}$

With regards, instead, to the question of whether the prohibition at issue goes beyond what is necessary for the attainment of the objective pursued, the Court states that, in contrast to the Pierre Fabre case, the clause here at issue does not contain an absolute prohibition imposed on authorised distributors to sell the contract goods online. Indeed, under that clause, the prohibition applies solely to the internet sale of the contract goods via third-party platforms which operate in a discernible manner towards consumers, ${ }^{41}$ also considering that, despite the increasing importance of thirdparty platforms in the marketing of distributors' goods, the main distribution channel, in the context of online distribution, is nevertheless constituted by distributors' own online shops, which are operated by over $90 \%$ of the distributors surveyed. ${ }^{42}$

The last question was related to the possibility of applying a block exemption should the referring Court find that the Metro criteria are not met in the specific case. In this regard, the Court denies that a clause like the one at stake constitutes a hardcore restriction. On the basis that it did not prohibit the use of the internet as a means of marketing the contract goods, the judges argue that the clause did represent neither a restriction of customers, within the meaning of Article 4(b) VBER, nor a restriction

\footnotetext{
${ }^{40}$ Paras. 44-51 of the Coty decision.

${ }^{41}$ Paras. 52-55 of the Coty decision.

${ }^{42}$ See "Final Report on the E-commerce Sector Inquiry", cited above, para. 39.
} 
of passive sales to end users, within the meaning of Article 4(c) VBER ${ }^{43}$. In fact, under the first profile, it does not appear possible to circumscribe, within the group of online purchasers, third-party platform customers. Under the second profile, the clause authorised distributors to advertise via the internet on third-party platforms and to use online search engines, with the result that customers are usually able to find the online offer of authorised distributors by using such engines.

\section{The Coty outcomes: a real turning point in the EU case law?}

The Pierre Fabre and Coty cases appear to establish two opposite principles: for the former, the aim of maintaining a prestigious image is not a legitimate aim for restricting competition; for the latter, on the contrary, it is, provided that the Metro criteria are met.

However, it is worth highlighting that, in reality, the Coty case represents a consolidation of established CJEU case law. The requirement that the characteristics of contracted goods are such as to necessitate a selective distribution system in order to preserve their quality and ensure its proper use was a later addition to the criteria set out in Metro, explicitly appearing for the first time in L'Oreal. ${ }^{44}$ The question of whether luxury goods were the type of goods which might satisfy this condition was later addressed by the General Court in Yves Saint Laurent ${ }^{45}$ and Givenchy. ${ }^{46}$ Expressing the same points drawn from Copad, the Court stated that the concept of characteristics of luxury goods cannot be limited to their material characteristics but also encompasses the specific perception that consumers have of them, in particular their "aura of luxury". The fact that luxury cosmetics are sold through selective distribution systems which seek to ensure that they are presented in retail outlets in an enhancing manner also contributes to that luxury image and thus, to the preservation of one of the main characteristics of the products which consumers seek to purchase. ${ }^{47}$

There was, thus, a danger that Pierre Fabre could be read as marking a reversal of the legal position concerning the legitimacy of the preservation of a luxury or prestigious image as an objective for a selective distribution system. The risk was even more serious after Pierre Fabre was relied on by the General Court in CEHAR. In the context of a selective repair system for prestigious watches operated by a group of Swiss watch manufacturers, the General Court found that "the aim of maintaining a prestigious image is not a legitimate aim for restricting competition". ${ }^{8}$ The General Court was bound by what, up until Coty, appeared to be an unambiguous statement on the legitimacy of that objective. Despite the Pierre Fabre precedent, the CJEU held that this decision cannot lead to the inference of a statement of principle according to which the preservation of a luxury image can no longer be such as to justify a restriction of competition.

The Coty decision is a robust affirmation of the economics of selective distribution for high-value goods expressed in the previous CJEU case law. ${ }^{49}$ Maintaining a strong brand image requires a chain of investments leading from pre-production all the way to the point of sale. Selective distribution systems are both a necessary and pro-

\footnotetext{
${ }^{43}$ Paras. 65-67 of the Coty decision.

${ }^{44}$ See Judgment of the Court of Justice, 11.12.1980, case 31/80, EU:C:1980:289.

${ }^{45}$ Judgment of the General Court, 12.12.1996, case T-19/92, EU:T:1996:190.

${ }^{46}$ Judgment of the General Court, 2.12.1996, case T-88/92, EU:T:1996:192.

${ }^{47}$ Paras. 6 and 115 of the Yves Saint Laurent judgment and 6 and 109 of the Givenchy decision.

${ }^{48}$ Judgment of the General Court, 23.10.2017, case T-712/14, EU:T:2017:748, para. 65.

${ }^{49}$ For an economic analysis of the European Commission's practice in vertical restriction cases, see Jonathan Faull and Ali Nipkay, The EU Law of Competition, $3^{\text {rd }}$ ed. (Oxford: Oxford University Press, 2014), 1363.
} 
competitive link in this chain. Besides, the Court reiterated that the Pierre Fabre assertion must be read and interpreted in light of the context of that judgment ${ }^{50}$ and according to the same Advocate General Wahl, the conclusion that luxury goods may require the implementation of a selective distribution system in order to preserve the quality of those goods cannot be called into question by the Pierre Fabre decision. ${ }^{51}$

Nonetheless, there are other issues that this decision seems to leave open. In the first place, one might wonder whether the Coty case law can be applied to agreements like the one that characterized the Pierre Fabre case, i.e. an absolute ban on internet sales. After Coty, it is left to clarify whether the conclusions enshrined in Pierre Fabre can be confirmed or whether maintaining a prestigious image could also justify these more restrictive clauses. It appears that it would be very hard for an absolute ban to satisfy the proportionality test required by the Metro case. Even though, theoretically speaking, it cannot be excluded that the online selling of some goods or services could negatively affect their prestige, the Court based the proportionality of the Coty clause on the fact that it did not contain an absolute prohibition imposed on authorised distributors to sell the contract goods online. Coty does not represent a real revirement of the Pierre Fabre case law and appears to confirm that an absolute ban represents a restriction by object of the competition.

Also, in relation to the applicability of the VBER, the Coty judgment does not seem to overcome the Pierre Fabre decision. In fact, in this regard as well, the fact that the Coty clause was not considered a hardcore restriction. Should the ban be absolute, also its qualification under Article 4 of the Regulation could be subject to change.

The second question left open by the Coty judgment concerns the possibility of applying its conclusions to other categories of vertical agreements other than the selective distribution agreements, e.g. exclusive distribution agreements or exclusive customer allocation agreements, when the prohibition of using third-party platforms are aimed at maintaining the prestigious image of the brand. Considering that the Metro criteria are not applicable to these other contractual models, the only way is assessing whether they can fall within the scope of the VBER. The answer should be positive, taking into account that the conditions laid out in the Coty case law would be met: the clause does not provide an absolute ban; it does not represent a restriction of customers either, since it is not possible to circumscribe, within the group of online purchasers, third-party platform customers, nor restriction of passive sales to end users, since the possibility to advertise via the internet on third-party platforms and to use online search engines enables customers to find the exclusive distributors' offers by means of such engines.

\section{The Geo-blocking Regulation: an added value for competitive markets}

In June 2017, after the Final Report on the E-commerce Sector Inquiry was released, the Commission opened a formal antitrust investigation into the distribution agreements and practices of the company Guess to assess whether it illegally restricted retailers from selling cross-border to consumers within the EU Single Market. In this respect, thanks to the insight gained from the sector inquiry, the Commission was able to target EU antitrust enforcement on the most widespread and problematic business

\footnotetext{
${ }^{50}$ Para. 31 of the Coty decision.

${ }^{51}$ Opinion of 26.7.2017, paras. 74-75.
} 
practices in e-commerce, which may negatively impact competition and cross-border trade, and hence the functioning of the European Digital Single Market.

Recently, the European Commission has sanctioned the company since Guess' distribution agreements tried to prevent EU consumers from shopping in other Member States by blocking retailers from advertising and selling cross-border. ${ }^{52}$ This allowed the company to maintain artificially high retail prices, in particular, in Central and Eastern European countries. In a competitive market, on the contrary, consumers should be free to purchase from any retailer authorised by a manufacturer, including across national borders, in order to find more choice and a better deal. At the same time, authorised retailers must be free to offer the products covered by the distribution contract online, to advertise and sell them across borders, and to set their resale prices.

On the same grounds, Nike was also fined by the European Commission in March 2019 for banning traders from selling licensed merchandise to other countries within the European Economic Area. This restriction concerned merchandising products of some of Europe's best-known football clubs and federations, for which Nike held the licence. ${ }^{53}$

These decisions represent a vivid example of how some selective distribution agreements, despite being necessary in the commercialization chain, can be used to affect cross-border competition online and offline, by limiting the possibility of shopping cross-border. Even though some limitations, if proportionate, can be allowed to pursue certain legitimate aims, some others, like the ones at stake, resulting in geoblocking tactics, represent an unlawful restriction of competition.

In order to face this sort of anticompetitive behaviour, the restriction of passive online sales, which was already assessed by the Commission in the 2010 Guidelines on Vertical Restraints, has been complemented by the adoption of the Regulation to prevent geographic blocking and other forms of discrimination against customers on

\footnotetext{
${ }^{52}$ Summary decision, 17.12.2018, case number AT.40428, last accessed 27.4.2019, available at http:// ec.europa.eu/competition/elojade/isef/case_details.cfm?proc_code=1_40428. In particular, the Commission investigation has found that Guess' distribution agreements restricted authorised retailers from: using the Guess brand names and trademarks for the purposes of online search advertising; selling online without a prior specific authorisation by Guess. The company had full discretion for this authorisation, which was not based on any specified quality criteria; selling to consumers located outside the authorised retailers' allocated territories; cross-selling among authorised wholesalers and retailers; and independently deciding on the retail price at which they sell Guess products. The agreements allowed Guess to partition European markets: the Commission has observed that in Central and Eastern European countries (Bulgaria, Croatia, Czech Republic, Estonia, Hungary, Latvia, Lithuania, Poland, Romania, Slovakia and Slovenia) the retail prices of Guess products are, on average, 5-10\% higher than in Western Europe.

${ }^{53}$ Press release of 25.3.2019, case number AT.40436, last accessed 27.4.2019, available at http:/ / europa. eu/rapid/press-release_IP-19-1828_en.htm. The Commission investigation has found that Nike's nonexclusive licensing and distribution agreements breached EU competition rules: Nike imposed a number of direct measures restricting out-of-territory sales by licensees, such as clauses explicitly prohibiting these sales, obligations to refer orders for out-of-territory sales to Nike and clauses imposing double royalties for out-of-territory sales; Nike enforced indirect measures to implement the out-of-territory restrictions, for instance threatening licensees with ending their contract if they sold out-of-territory, refusing to supply "official product" holograms if it feared that sales could be going towards other territories in the European Economic Area (EEA), and carrying out audits to ensure compliance with the restrictions; Nike included clauses that explicitly prohibited licensees from supplying merchandising products to customers, often retailers, who could be selling outside the allocated territories. In addition to obliging licensees to pass on these prohibitions in their contracts, Nike would intervene to ensure that retailers (e.g. fashion shops, supermarkets, etc.) stopped purchasing products from licensees in other EEA territories.
} 
grounds of nationality, place of residence or place of establishment (so-called GeoBlocking Regulation)..$^{54}$ This Regulation, applicable as from 3 December 2018, is one of the main measures adopted within the Digital Single Market Strategy.

Geo-blocking refers to practices used by online sellers that result in the denial of access to websites from other Member States. It also includes situations where access to a website is granted, but the customer from abroad is prevented from finalising the purchase or being asked to pay with a debit or credit card from a certain country. Geo-discrimination also takes place when buying goods and services offline, e.g. when a consumer is physically present at the trader's location but is either prevented from accessing a product or service or being offered different conditions.

The Regulation prohibits geo-blocking and other geographically-based restrictions which undermine online shopping and cross-border sales by limiting the possibility for consumers and businesses to benefit from the advantages of online commerce. It addresses the problem of (potential) customers not being able to buy goods and services from traders located in a different Member State for reasons related to their nationality, place of residence or place of establishment, hence discriminating against them when they try to access the best offers, prices or sales conditions compared to nationals or residents of the traders' Member State. ${ }^{55}$ Boosting cross-border e-commerce is one of the main objectives of the Digital Single Market. Fully harmonised digital contract rules and strengthened rules on cooperation between national consumer protection authorities will improve consumer protection and conditions for businesses selling products and services across borders. The fully harmonised set of rules on digital contracts will reduce the differences between national consumer contract laws and remove one of the main reasons why businesses 'geo-block'. ${ }^{56}$

The most important novelty introduced by the Regulation is the direct identification of some situations where a differentiated treatment among clients, on geographic grounds, is not objectively justified.

\footnotetext{
${ }^{54}$ Regulation (EU) 2018/302 of the European Parliament and of the Council of 28.2.2018 on addressing unjustified geo-blocking and other forms of discrimination based on customers' nationality, place of residence or place of establishment within the internal market and amending Regulations (EC) No. 2006/2004 and (EU) 2017/2394 and Directive 2009/22/EU, in OJ L 60I of 2.3.2018, 1-15. See Klaudia Majcher, "E-Commerce in the EU: Searching for Coherence of Data Protection and Competition Law in the Context of Geo-Blocking", Columbia Journal of European Law 24 (2018): 577 595; Valérie Ruotolo and Michela Anna Andreoletti, "I destini incrociati di antitrust e e-commerce: dalle iniziative della Commissione europea alla recente sentenza della Corte di giustizia", Diritto del commercio internazionale 32 (2018): 361-384, at 369; Celeste Pesce, "Blocchi geografici ingiustificati", Post AISDUE (2019): 13-25, last accessed 29 April 2019, available at https:/ /www.aisdue.eu/blocchigeografici-ingiustificati-unjustified-geo-blocking.

${ }_{55}$ According to Article 1(1), in situations not covered by the Geo-blocking Regulation, Article 20(2) of the Services Directive (2006/123/EC) can be applicable. According to this provision, traders may only apply differences of treatment based on nationality or place of residence if this is justified by objective criteria. In some cases, sector-specific legislation (for instance in the field of transport, or health) may also apply which addresses this issue. In addition, the Regulation leaves the rules of the TFEU unaffected, including its rules on non-discrimination.

${ }^{56}$ Communication from the Commission to the European Parliament, the Council, the European Economic and Social Committee and the Committee of the Regions on the Mid-Term Review on the implementation of the Digital Single Market Strategy, "A Connected Digital Single Market for All”, Brussels, 10.5.2017, COM(2017) 228 final, para. 2. According to recital 23 of the Geo-Blocking Regulation, harmonised rules do not imply free cross-border delivery of goods.
} 
Very briefly, in a context of a cross-border transaction, ${ }^{57}$ Articles 3-5 of the Regulation ban for reasons related to the customer's nationality, place of residence or place of establishment, the blocking or limitation of a customer's access to the trader's online interface (as well as re-routing without the customer's prior consent); the application of different general conditions of access to goods or services; and the application of different conditions for a payment transaction.

These provisions increase price transparency by allowing customers to access different national websites. For instance, before the entry into force of the Regulation, if a Portuguese customer wants to access the Italian site of an online clothes retailer, even though the costumer types in the URL of the Italian version, she gets redirected to the Portuguese version. After the entry into force of the Regulation such redirection will require the explicit consent of the customer and even if the customer gives consent to the redirection, the original version she sought to visit should remain accessible.

The rules of the Regulation apply in principle to both business-to-consumer (B2C) and to business-to-business (B2B) transactions, to the extent that the latter take place on the basis of general conditions of access (hence they are not individually negotiated) and the transaction is for the sole purpose of end use (hence made without the intention to re-sell, transform, process, rent or subcontract).

Coming to the core question of the present analysis, which is the coordination between the Geo-blocking Regulation and competition rules, this is regulated by Article 6 of the Regulation. This Article contains three categories of provisions.

The first paragraph establishes that, without prejudice to the VBER and Article 101 TFEU, this Regulation shall not affect agreements restricting passive sales within the meaning of the former Regulation, that concern transactions falling outside the scope of the prohibitions laid down in Articles 3-5 of this Regulation. This provision, despite appearing rather obscure, is substantially aimed at preserving the application of competition rules when agreements limiting passive sales on grounds other than nationality, place of residence or place of establishment (and therefore falling outside the scope of application of the Geo-blocking Regulation) are concluded. On the contrary, when the agreement falls within the scope of application of such Regulation, its provisions overlap with competition rules. In this case, being lex specialis, the Geoblocking Regulation rules should prevail. ${ }^{58}$ The Regulation, however, cannot prevail over Article 101 TFEU: therefore, despite being very rare in practice, theoretically speaking, an individual exemption under Article 101(3) TFEU could not be excluded.

Under the Regulation, a supplier cannot contractually prohibit a retailer from responding to unsolicited customer requests in the specific situations covered by the Regulation. In the case of the Guess decision, Guess' practices that restricted passive sales to consumers are now also prohibited by the Geo-blocking Regulation.

In addition, the first paragraph of Article 6 of the Geo-blocking Regulation specifies that its provisions are inapplicable to agreements limiting active sales. This provision is clearer than the previous one and intends to preserve the admissibility the restrictions to active sales already allowed, under certain circumstances, by the VBER.

\footnotetext{
${ }^{57}$ According to Article 1(2), the Regulation does not apply to purely internal situations. Also Recital 7 states that the Regulation should not apply to situations "where all the relevant elements of the transaction are confined to a single Member State, in particular the nationality, the place of residence or the place of establishment of the customer or of the trader, the place of execution, the means of payment used in the transaction or the offer, as well as the use of an online interface".

${ }^{58}$ Pietro Manzini, "Le restrizioni verticali della concorrenza al tempo di internet", Diritto del commercio internazionale 32 (2018): 289-320, at 296; Celeste Pesce, "Blocchi geografici ingiustificati", cited above, 22.
} 
If this was not the case, it would not be possible to conclude exclusive distribution agreements or exclusive customer allocation agreements.

Finally, according to the second paragraph of Article 6, provisions of agreements imposing obligations on traders, in respect of passive sales, to act in violation of the prohibitions laid down in Articles 3-5 of the Regulation shall be automatically void. Not only does this provision confirm Article 101(2) TFEU, but it also goes beyond that. In fact, where an exemption applies, or where contractual restrictions are not covered by Article 101 TFEU, there is a risk that they could be used to circumvent the provisions of this Regulation. The relevant provisions of such agreements should therefore, be automatically void where they impose obligations on traders to act in breach of the prohibitions laid down in this Regulation regarding access to online interfaces, access to goods or services and payment. Those provisions concern, for example, contractual restrictions that prevent a trader from responding to unsolicited requests from individual customers for the sale of goods, without delivery, outside the trader's contractually allocated territory for reasons related to customers' nationality, place of residence or place of establishment. Therefore, the importance of the Geoblocking Regulation is strictly related to its complementing competition rules when they do not apply to a specific case. ${ }^{59}$

This is confirmed also in another possible situation. It has to be taken into account that e-commerce's fast development, made possible also by the rules that prohibit restrictions on online passive sales, encounters a rather important obstacle when the seller decides autonomously (and not on the basis of contractual clauses like selective distribution agreements) not to sell outside a certain territory or a certain category of clients. In these circumstances, in fact, antitrust rules prove to be rather ineffective. On the one hand, Article 101 TFEU, implying an agreement between two or more companies, cannot be applied; on the other, Article 102 TFEU, applicable also to unilateral conducts, presupposes that the company in question holds a dominant position, which is not always the case and which is verifiable only with very complex economic assessments.

We are not referring to cases where a supplier or a distributor decides not to sell online, such situations constitute decisions on how to conduct a business activity, but to cases where they refuse to respond to orders coming from outside a certain territory or group of clients. This kind of practice is now dealt with by the geo-blocking rules that address the issue of sales restrictions that are at odds with the Single Market.

\section{Final remarks}

In several public speeches, the Commissioner for Competition Vestager has underlined the importance of the digital economy and affirmed that it is still possible to "talk. today about 'digital markets' - still think of our economy as being divided into parts that are digital, and others that aren't. But that won't be true for much longer. (...) And very soon, there will be no such thing as digital markets - just a digital world'. ${ }^{60}$

\footnotetext{
${ }^{59}$ Ben Van Rompuy (editorial), "A Europe without Digital Borders: Beyond the Reach of Antitrust", European Competition and Regulatory Law Review 1 (2017): 93-95.

${ }^{60}$ Speech of 4.4.2019, Defending competition in a digitised world, Bucharest, last accessed 27.4.2019, available at https://ec.europa.eu/commission/commissioners/2014-2019/vestager/announcements/ defending-competition-digitised-world_en. Similarly in the speech of 8.4.2019, Competitiveness in a digital age, Paris, last accessed 27.4.2019, available at https://ec.europa.eu/commission/ commissioners/2014-2019/vestager/announcements/competitiveness-digital-age_en.
} 
This statement was made short after the Report on Competition Policy in the Digital Age was released. ${ }^{61}$ The Report makes clear that, despite all the changes that digital technology has brought to our markets, the basic principles of competition policy are as relevant as ever. The trouble is that some of those changes have made it harder than ever to keep competition working the way it should. Even earlier, when the Preliminary Report on the E-Commerce Sector Inquiry was published in 2016, the Commissioner for Competition expressed her hope that that Report worked as a "trigger for companies to review their current distribution contracts and bring them in line with $E U$ competition rules if they are not". 62

All these stances make it clear how, in the digital landscape, competition rules, that do not per se sufficiently take into account all the new possible restrictions that technology enables, need to be read in a such a way that this new scenario does not negatively impact markets and consumers.

The case law of the CJEU is helping in this respect trying to find a fair balance between guaranteeing the use of online channels for distributors and customers and protecting some legitimate interest of the suppliers. Whilst the Pierre Fabre decision established that an absolute and general ban of online sales amounts to a restriction by object, the Coty judgment admitted that, under certain conditions, some limitation (especially related marketplaces bans) can be accepted.

However, besides the question of whether the Coty case law can be applied to absolute bans and to agreements like exclusive distribution agreements or exclusive customer allocation agreements, which are still to be clarified by the case law, other critical elements remain unsolved that regard the very conclusion drawn by the Court in that decision. Its application, in fact, can become rather subjective when it comes to define what is a luxury product and when the need to protect a luxury image arises. This assessment involves a certain degree of discretion, as well as the possibility to extend the Coty case law, more generally, to quality products. ${ }^{63}$ In a context, like the European one, where European competition rules are mainly applied by national authorities, this margin of discretion can lead to very different outcomes in the various Member States, affecting long-term predictability in contractual relations. For instance, the German Federal Supreme Court, in the ASICS case, confirming the position opted for a restrictive view by establishing that the Coty case law applies narrowly to luxury products and not quality products. ${ }^{64}$ In the Court's view, this conclusion was

\footnotetext{
${ }^{61}$ Final Report by Jacques Crémer, Yves-Alexandre de Montjoye, Heike Schweitzer, 2019, last accessed 27.4.2019, available at http:/ / ec.europa.eu/competition/publications/reports/kd0419345enn.pdf. ${ }^{62}$ Speech of 15.9.2016, Competition and the Digital Single Market, Paris, last accessed 27.4.2019, available at https://ec.europa.eu/commission/commissioners/2014-2019/vestager/announcements / competition-and-digital-single-market_en.

${ }^{63}$ In the Competition policy brief of April 2018, last accessed 27.4.2019, available at http://ec.europa. eu/competition/publications/cpb/2018/kdak18001enn.pdf, DG Competition has delivered an interpretative note on the Coty judgment called "EU competition rules and marketplace bans: Where do we stand after the Coty judgment?", in which argues that the arguments provided by the Court in Coty case "are valid irrespective of the product category concerned (...) and are equally applicable to non-luxury products. Whether a platform ban has the object of restricting the territory into which, or the customers to whom the distributor can sell the products or whether it limits the distributor's passive sales can logically not depend on the nature of the product concerned. In DG Competition's view, marketplace bans therefore do not amount to a bardcore restriction under the VBER irrespective of product category concerned' (p. 4). In any case, as the note says, these conclusions represent the authors' view on the matter and do not bind the Commission in any way.

${ }^{64}$ Bundesgerichtshof, 12.12.17, KVZ 41/17, last accessed 27.4.2019, available at http://juris. bundesgerichtshof.de/cgi-bin/rechtsprechung/document.py?Gericht=bgh\&Art=en\&Datum=Aktuell\&S
} 
so stiff that was not even necessary to refer to the CJEU for a preliminary ruling. According to the decision, per se prohibitions (i.e. suppliers' prohibition to their dealers from using price comparison engines) which are not tied to quality requirements are illegal. It made reference to both the Pierre Fabre and Coty cases and held the view that in contrast to high-priced cosmetic goods, ${ }^{65}$ sports and running shoes are not luxury goods. On the other hand, in a similar case, the Dutch authorities, referring to the same Coty case law, drew an opposite conclusion and ruled in favour of sports goods manufacturer Nike in an action against a distributor, which had not complied with Nike's selective distribution policy. The District Court of Amsterdam found that Nike's selective distribution system, which included a ban on sales via non-authorised online platforms, was compatible with competition law as it sought to preserve the luxury image of Nike's products. ${ }^{66}$

These issues show how competition law is still finding its way to adapt to the new digital scenario. Certainly, the Geo-blocking Regulation has added a new piece to the picture and helped to solve some situations that could not be directly connected to antitrust provisions. However, new interventions of the CJEU are much awaited in order to bring more clarity to a scenario, like the digital economy, that, despite having become a reality in commercial relations, it still does not completely adjust to the present competition rules.

ort $=12288 \& \mathrm{kr}=80673 \& \mathrm{xpos}=25 \& \mathrm{knz}=515$. See a note of the German Competition Authority, "ASICS dealers allowed to use price comparison engines - Federal Court of Justice confirms Bundeskartellamt's decision", 25.1.2018, last accessed 27.4.2019, available at https://www.bundeskartellamt.de/ SharedDocs/Meldung/EN/Pressemitteilungen/2018/25_01_2018_Entscheidung_Asics.html.

${ }^{65}$ For an some Italian cases applying Coty case law to high-priced cosmetics, see Tribunal of Milan, 19.11.2018, case 38739/2018, L'Oreal Italia s.p.a. e Helena Rubinstein Italia s.p.a. v IDS International Drugstore Italia s.p.a.; Tribunal of Milan, 18 December 2018, case 44211/2018, Landoll s.r.l. v Mecs s.r.l. See Francesco Banterle, "Two recent decisions on selective distribution and infringement of luxury trademarks from the Court of Milan”, IP lens blog, 6.2.2019, last accessed 27.4.2019, available at https://iplens.org/2019/02/06/two-recent-decisions-on-selective-distribution-and-infringement-ofluxury-trademarks-from-the-court-of-milan/.

${ }^{66}$ See Andrzej Kmiecik, "European Union: Dutch Court Renders Judgment On Legality Of Nike's Platform Sales Restrictions”, 28.11.2017, last accessed 27.4.2019, available at http://www.mondaq. $\mathrm{com} / \mathrm{x} / 650362 /$ Antitrust+Competition/Dutch +Court+Renders+Judgment+On+Legality+Of+ Nikes+Platform+Sales+Restrictions. 